\title{
Floods and droughts as a result of deformability of the geological environment
}

\author{
Anastasiya Kapochkina
}

The Environmental Inspection of the Ministry of Environment of Ukraine, leading expert - state inspector, state environmental inspectorate of the North-Western Black sea (Odesa), State Environmental Inspectorate Northwestern Black Sea region Head, 12 line 6 station Lustdorfska Road 22,65114 Odessa, Ukraine, e-mail: nastia-82@mail.ru

\section{Borys Kapochkin}

Odessa National Academy of Telecommunications, Kuznechnaya Street 1,65029Odessa, Ukraine, e-mail: tsb1@ukr.net

Natalia Kucherenko

Odessa State Environmental University, Lvivskaya Street 15, 65016 Odessa,Ukraine, e-mail: tsb1@mail.ru

\section{Igor Uchytel}

Odessa State Academy of Civil Engineering and Architecture, Didrihsona Street 4, 65029 Odessa, Ukraine, e-mail: sch@odgaz.odessa.ua

\begin{abstract}
The water content of the rivers is formed by atmospheric precipitation and underground waters. Influence of underground waters on water content of the rivers cannot be measured. It is shown that the volume of underground water exchange is underestimated and can be commensurable with a volume of atmospheric precipitation. Change of level of underground waters is defined by changes of volume of the geological environment during geodeformations. It is offered to consider geodeformations as one of the reasons of floods and droughts. Studied the changes the gravitational field and geodeformations during droughts and floods in the Amazon in 2005-2006. Studied the hydrological regime of the River Nile. Shows the influence of geodeformation on the level of Danube and Dniester. Proposed detailed study the causes of floods in Europe in 2002. Influence of the Earth's surface deformation on floods and droughts is very important and requires special detailed study. Changes in volume of rocks during Earth's surface deformation are accompanied by dilatancy which influence on the amount of drought and flooding has turned out to be significant. Study of the processes considered in the thesis gives grounds to expect that floods and droughts associated with deformations of the geological environment will be successfully predicted.
\end{abstract}

Keywords: rivers level, gravitational field, Amazon, Nile, GPS permanent network

Submitted 23 June 2014, revised 25 November 2014, accepted 14 July 2015

\section{Introduction}

Among natural disasters, drought has one of the most serious influences on human death-tolls, while floods are the most impactful in terms of economic damage. For example, the drought of 2005 in the basin of the world's biggest river, the Amazon, had catastrophic consequences, and not only for Brazil and Argentina. Losses in agriculture and animal breeding contributed to the 2008 world food crisis. Droughts and floods are usually caused by either the absence or surplus of atmospheric precipitation. This research deals with the task of estimating the influence of deformations of the surface of the Earth on the formation of droughts and floods.

The research paper (Vartanyan 1998) contains the results of the measurement of volume changes in rocks in the period prior to earthquakes. This volume increase can reach $2 \%$. Thus, as a result of this increase in the volume of the geological environment, $1 \mathrm{~m}^{3}$ of rock is capable of absorbing 20 litres of water. The phenomenon of rock volume change featuring water is called dilatancy.

Shilo's thesis (1989) demonstrates data on the lithosphere absorption of $84 \mathrm{~km}^{3}$ in the Caspian Sea waters prior to an earthquake in $1894(\mathrm{M}=8.2)$; and of $85 \mathrm{~km}^{3}$ before an earthquake in $1889(\mathrm{M}=5.9)$. These data demonstrate that volumes of water withdrawal and allocation from a lithosphere, during its deformations, can be crucial. Water exchange volumes between the lithosphere and the Caspian Sea correlate with earthquakes, as does the anomaly in ground water inflow and the chemical composition of the rivers of the Caspian region (Shilo 1989). 


\section{Relevance of the research}

Verification of the thesis about the primary influence of atmospheric precipitation on droughts and floods is necessary. Let us firstly review the example of an extreme drought of 2005 in a basin of the Amazon River (with an average annual discharge of water $6930 \mathrm{~km}^{3}$ ). Over a period of three months of atmospheric precipitation deficiency, the Amazon River significantly dried up. In some places the water level decreased by $14 \mathrm{~m}$. However, after some months the drought gave way to a flood. Let us consider the reasons for the drought in accordance with the data provided by the research paper (Marengo et al. 2008). In June $2005,67 \%$ of the mean annual precipitation fell in the Amazon River basin. In July this figure was 33\% and in August it was $67 \%$. The drought gave way to a severe flood, in February 2006. The change, within several months, from a catastrophic drought to a severe flood within the basin of the world's largest river was something the authors couldn't explain through atmospheric precipitation anomalies. The dependence of this drought on climatic anomalies was also studied. The drought did not affect central or eastern Amazonia, a pattern different from the El Niño-related droughts in 1926, 1983 and 1998. The causes of the drought were not related to El Niño. The Amazon drought of 2005 differed from droughts caused by climatic changes. During droughts, significant rainforest areas usually perish. However, in 2005 the Amazonian woods degree of greenness, on the contrary, significantly increased (http://elementy.ru/news/430620). In the research paper (Marengo et al. 2008) it is stated that the reason for the Amazon drought of 2005 has not been defined.

This example shows that the rapid fall in the level of the largest river in the world (by $14 \mathrm{~m}$ ) and the equally large fast flood within a few of months can't be explained by atmospheric precipitation anomalies. This means that there are other reasons for droughts and floods, and these reasons are capable of withdrawing and returning huge amounts of water from the riverbed.

It's worth mentioning that September 2005 was distinguished by abnormal geological deformations on a global scale (Voitenko et al. 2007). In September the crust of the Earth in Ethiopia spread by $8 \mathrm{~m}$ - this observation was unprecedented in the history of human civilization. The length of the crack was $60 \mathrm{~km}$.

In the research paper (Konkin et al. 2006) we made the assumption that the drought of 2005 occurred due to deformations on a continental scale. These deformations were accompanied by anomalies of seismic activity in the West, in the subduction zone, and regional anomalies of the gravitational field of the Earth. In the research paper
(Chen et al. 2009) it was shown that during the drought within the basin of the Amazon River there was an abnormal reduction of gravity. In July and August 2005, gradients of gravity decrease were extremely high. The data on extreme geological deformations in the drought zone are provided in the research paper (Rudenko et al. 2013). The measured deformations of the Earth's surface exceed its background vertical shifts by $300 \%$. A GPS station (BRAZ) established that from April 2005 to March 2007 the geodetic control point fell by approximately $7-8 \mathrm{~cm}$. Over 10 years of the (BRAZ) GPS station's observation, 6 fluctuations have been measured (Rudenko et al. 2013). In our opinion, the duration of oscillations, and the oscillations themselves, are due to the Chandler period. There is a hypothesis that Chandler oscillations reflect the process of the Earth's lithosphere lag from its internal covers at its rotation round its axis (Voitenko et al. 2007). When studying Chandler oscillations during the 2005 Amazon River drought, the process was characterized by an unprecedented anomaly. During this period, global reversive geodynamic movements (Voitenko et al. 2007) were observed.

The most objective results of the assessment of the impact of changes in the volume of the geological environment on the water content of rivers can be obtained by studying rivers that are not considered to have a rainfed stream. For these rivers volume flow depends on hydrogeology. Normally, the flow of rivers depends on rainfall and hydrogeology. Differentiating between the influences of these factors is difficult. In this aspect, we can consider the hydrological regime of the River Nile. This river is separated from sources of rainwater supply by a dam. Below the dam the river flows for about $1000 \mathrm{~km}$ in the Sahara desert. The width of the floodplain near Aswan reaches $2 \mathrm{~km}$, and in delta-front areas it reaches $20 \mathrm{~km}$. The Nile delta has a width of $250 \mathrm{~km}$. The Nile discharge at the Aswan dam is $2600 \mathrm{~m}^{3}$, and near its mouth it is $2900 \mathrm{~m}^{3}$ (http://dic.academic.ru/dic.nsf/enc geo/196/НИЛ). The Nile water over the river's whole length is actively selected for irrigation. Despite the river flow loss due to evaporation and water extraction for domestic needs, the river discharge at its mouth exceeds the discharge near the Aswan dam. In the absence of a rain-fed stream, the abovementioned facts are yet to be explained. No studies on this issue are available.

Moreover, it is difficult to explain the reasons for flood flow in the hot season when evaporation and transpiration are at the maximum level. To explain this phenomenon it should be taken in account that the bed of the investigated area of the Nile is situated on the eastern border of the province of groundwater (http://planetolog.ru/map-world). 
An important factor is that in the Nile flood season there have been annually observed extreme changes in the Earth's shape, which form the annual maximum of its rotational angular velocity.

The catastrophic anomalies of the hydrological regimes of the largest river in the world, the Amazon, and the longest river running through desert, the Nile, are outlined above. The revealed violations of the hydrological regimes of rivers are connected with the withdrawal and allocation of large water quantities through processes of unknown nature from the river. This confirms the necessity for studying the probable dependence of the water content of rivers on the deformation of the Earth's surface.

\section{Previous study of the problem}

In the research paper (Kapochkin 1993) the conditions of the activation of geodynamic processes in south-eastern Europe in 1939-1942 are studied. During those years, earthquakes rated 10-11 on the MSK-64 scale took place in Romania and Turkey. At this time, the average water discharge of the Danube and the Dniester increased by $50 \%$. In the research paper (Mikhailov et al. 2010) it is shown that, at the same time, the level of the drainless Kuyalnik estuary rose by more than 3 metres (fig. 1). Below, the thesis (Rozengurt 1974) regarding the simultaneous rise of the levels of the Tiligul and the Khadzhibey estuaries is shown.

Figure 1 demonstrates that the abnormal estuary level rise was not caused by abnormal rain. The high level of the estuary remained abnormally high for ten dry years, and then dropped below the previous level for no apparent reason. It can be assumed that the simultaneous rise of the levels of the Danube, the Dniester and the Black Sea estuaries may have occurred due to changes in the volume of rock deformation in the active surface of the Earth.

In the research paper (Kapochkina, Kapochkin 2004) the causes of simultaneous changes in the Dniester (in the Dniester region through which it flows) and the Danube

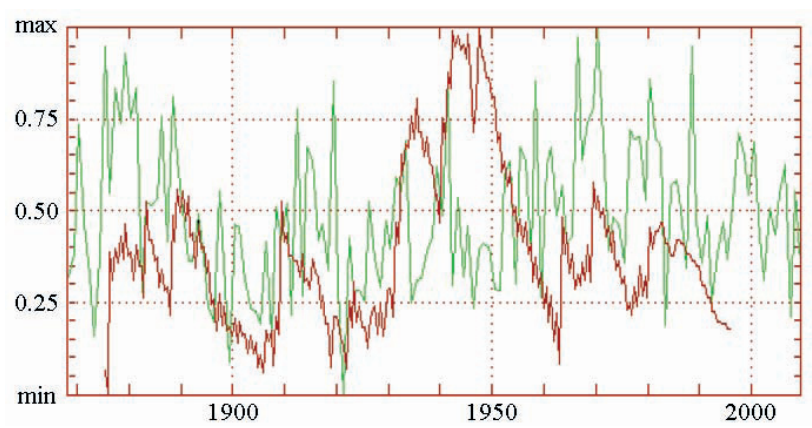

Fig. 1. The combined schedule of relative change of average monthly values of the Kuyalnik estuary level (red) and atmospheric precipitation volume (green) (in Kiliya and Izmail regions) levels in August 2003 (fig. 2) are studied. Simultaneous level changes are connected with the deformation before strong earthquakes in Greece on August 14, 2003. On August 12-13, active geological deformations were observed in Eastern Europe. These were discovered as a result of the emergence of regional changes in the Earth's gravitational field (Voitenko et al. 2007). Judging by the nature of the local changes in gravity, they manifested themselves as lithospheric extension. The Danube (Izmail and Kiliya) and the Dniester (Mayaki) level reduction reached $50 \mathrm{~cm}$ (fig. 2) during the geological deformations of May 12 and 13, 2003.

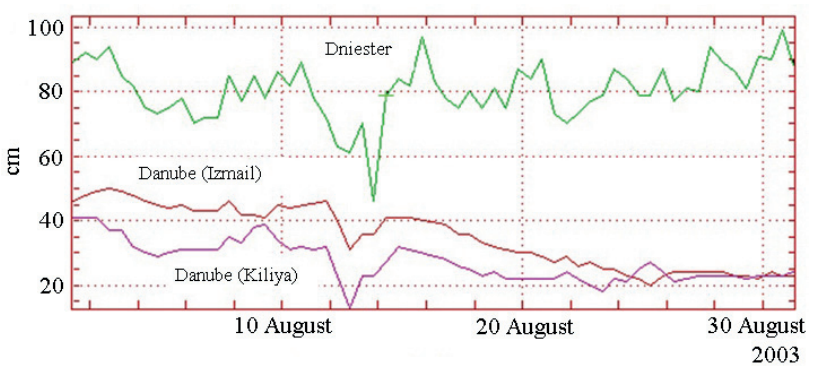

Fig. 2. Changes of the Dniester (Mayaki) and the Danube (Izmail and Kiliya) water level (Mikhailov et al. 2010)

The research paper (Konkin et al. 2004) investigated the periodic changes in the Danube level in 1995. Figure 3 shows the changes in the Danube level against the background of changes in the season.

In the example of the Danube, over 7-10 days the river level periodically rose and fell by $50-100 \mathrm{~cm}$. The level oscillation period comprises 1 month. Below are the results of calculations of the coherence function, the phase shift function, the correlation coefficient between the Danube level oscillations periodic component and monthly tides in the Solid Earth.

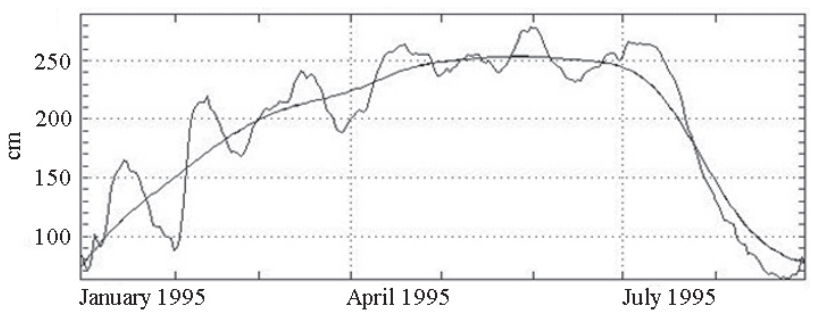

Fig. 3. Danube water level changes: (a) - in Izmail; and the diagram of the low frequency component (b) (Konkin et al. 2004)

Coherency values were $\hat{J}=0,968$; phase shift was $\Delta \varphi=$ $11^{\circ}$; correlation coefficient was $\dot{r}=+0,93$. The calculations show the coincidence of oscillations in the Danube level and the Earth's surface deformation caused by the diurnal tides in the Solid Earth. The Earth's surface deformation can generate changes in the Danube level equivalent to the spring flood volume. 


\section{Prospects for further research}

According to the World Meteorological Organization (http:/www.vokrugsveta.ru/vs/article/436/), in 2002 floods killed three thousand people and deprived 17 million people of their homes in over 80 countries. A territory of a total area of more than 8 million $\mathrm{km}^{2}$ was flooded. The total damage caused by flooding is estimated at $\$ 30$ billion. 2002 is considered abnormal in its number of floods.

In the research paper (Uchytel et al. 2008) it is shown that the global geodynamic conditions of 2001 and 2002 were also significantly different from the norm. The compression index of rocks for this time period is depicted as an independent geodynamic epoch. The connection between the floods in 2002 and the deformations in the Earth's surface requires detailed consideration.

The summer floods in Europe of 2002 began on June 6-8 with catastrophic flooding in the south of Germany. The dependence of the mentioned flooding on geodynamic processes is considered in the monograph (Uchytel et al. 2008).

Two weeks later, on June 20-22, there were catastrophic floods on both the Kuban River and the Terek River. The geodynamic conditions of these floods are described in the study (Uchytel et al. 2008).

The next catastrophic flooding occurred in early August 2002 in Europe and the Caucasus. So, overall, catastrophic simultaneous floods occurred in different regions on June 6-8, June 20-22 and August 8-10, under the same geodynamic conditions. Geological deformations related to regional tides in the Solid Earth comprised a period of 14 days. These deformations significantly changed the shape of the Earth. Changes in the shape of the Earth affect the angular velocity of its rotation. The floods in southern Germany (on June 6-8, 2002) as well as on the Kuban River and the Terek River (on June 20-22, 2002), and also in Europe and in the north of the Caucasus (on August 8-10, 2002), occurred under the conditions of the minimum angular velocity of the rotation of the Earth.

The flood on June 22, 2002 in the north of the Caucasus is considered abnormal. The flood anomaly lay in the fact that it occurred simultaneously in two river basins - the Kuban River and the Terek River. In the research paper (Volosuhin, Tkachenko 2013) it is indicated that floods in the Caucasus have previously covered only a part of the basin of a single large river. There had been no noted cases of flooding having occurred simultaneously in the basin of the Kuban River and the Terek River before 2002. The catastrophic floods of June 20-22, 2002 were unexpected. Atmospheric precipitation was not enough to induce the occurrence of a disaster on this scale (Mikhailov et al. 2010).
The reasons for the synchronous catastrophic floods in Europe and the Caucasus in August 2002 were considered by Von Ute Reissner in his thesis Hochwasserkatastrophe in Europa (2002). Causal factors of the flooding appear to be similar to the summer floods in east Germany and Poland of 1998. In summer 1998, anomalous rain storms were also observed in Odessa. As in Europe, this anomalous rainfall lasted for three months during the period typical for low rainfall. The influence of the deformation of the Earth's surface on the formation of showers in this period is confirmed by our studies of the drainage flow of groundwater in the Black Sea. As a rule, the salinity of the sea water in the area of drainage water discharge decreased sharply before the storm rainfall.

\section{Conclusion}

The influence of the deformation of the Earth's surface on floods and droughts is very important and requires special detailed study. Changes in rock volume during the deformation of the Earth's surface are accompanied by dilatancy, the influence of which on the amount of drought and flooding appears significant. The study of the processes considered in this thesis gives grounds to expect that floods and droughts associated with deformations in the geological environment will be successfully predicted.

\section{Bibliography}

Chen J.L., Wilson C.R., Tapley B.D., Yang Z.L., Niu G.Y., 2009, 2005 drought event in the Amazon River basin as measured by GRACE and estimated by climate models, Journal of Geophysical Research: Solid Earth, 114 (B5), 1-9, DOI: 10.1029/2008JB006056

Kapochkin B.B., 1993, The disturbance of ecological balance in the hydrosphere as a sequence of tectonic process activation. Modelling and control, CAMSE Press, 3, 35-44

Kapochkina A.B., Kapochkin B.B., 2004, Changes in the environment before the Greek earthquake (14.08.03), [in:] Proceedings of the $5^{\text {th }}$ International Symposium on Eastern Mediterranean Geology, A.A. Chatzipetros, S.B. Pavlides (eds.), Thessaloniki, Greece, 587-590, available at http:// www.geo.auth.gr/5thISEMG/Documents/Presentation\%20 schedule.pdf (data access 1.10.2015)

Konkin V.V., Kapochkin B.B., Kucherenko N.V., 2004, Some aspects of the formation of flooding, taking into account the impact of hydrogeodynamic processes, Meteorologiya, klimatologiya, gidrologiya, 47, 276-283

Konkin V.V., Kucherenko N.V., Kapochkin B.B., Lisovodsky V.V., 2006, Drought in South America, an analysis of its causes, Preprint, EGU, Viena, 235-236 
Marengo J.A., Nobre C.A, Tomasella J., Oyama M.D., de Oliveira G.S., de Oliveira R., Camargo H., Alves L.M., 2008, The drought of Amazonia in 2005, Journal of Climate, 21 (3), 495-516, DOI: 10.1175/2007JCLI1600.1

Mikhailov V.I., Kapochkina A.B., Kapochkin B.B., 2010, Interaction in system lithosphere-hydrosphere, Odessa: Astroprint Publisher, 153 p., available online at http://liber.onu. edu.ua/opacunicode/index.php?url=/notices/index/IdNotice:370194/Source:default (data access 1.10.2015)

Reissner U. von, 2002, Hochwasserkatastrophe in Europa, World Socialist Web Site, available at https://www.wsws.org/de/ articles/2002/08/hoch-a21.html (data access 1.10.2015)

Rozengurt M.A., 1974, Hydrology and prospects for reconstruction of the natural resources of the Odessa estuaries, scientific thought, Academy of Sciences, USSR, 225 p., available at http://www.twirpx.com/file/718099/ (data access 1.10.2015)

Rudenko S., Schön N., Uhlemann M., Gendt G., 2013, Reprocessed height time series for GPS stations, Solid Earth, 4, 23-41, DOI: 10.5194/se-4-23-2013
Shilo N.A. 1989, Relationship level fluctuations of the Caspian Sea, with emphasis on the crust, Journal of the Academy of Sciences of the USSR, 83-90

Uchytel I.L., Dorofeev V.S., Yaroshenko V.N., Kapochkin B.B., 2008, Geodynamics. Fundamentals of dynamic geodesy, Odessa: Astroprint Publisher, 312 p., available at http://uchebilka.ru/geografiya/101480/index.html (data access 1.10.2015)

Vartanyan G.S., 1998, GGD-monitoring as a key technology of short-term and operational forecasting earthquakes, Preprint - experience of a comprehensive study of the geophysical fields for seismographic forecasting, Moscow, 10-12

Voitenko S.P., Uchytel I.L., Yaroshenko V.N., Kapochkin B.B., 2007, Geodynamics. Fundamentals of kinematic surveying, Odessa: Astroprint Publisher, 264 p.

Volosuhin V.A., Tkachenko J.J., 2013, Predicting the parameters of floods on the rivers of the Krasnodar Territory, Hydraulic Engineering, 4 (33), 16-20, available at http://hydroteh.ru/ download/journal/archive/G4\%2833\%292013.pdf (data access 1.10.2015) 